\title{
The Challenges of Effective Teaching and Learning of English in Public Secondary Schools in Nigeria
}

\author{
Murana, Muniru Oladayo: Department of European Languages, Federal University Birnin-Kebbi, Kebbi State, \\ Nigeria.
}

\begin{abstract}
The strategic place of English language in national development and mutual co-existence of Nigerians is not debatable. English has become a foreign national language to which the destiny of Nigeria is inextricably tied. The teaching of English at all levels of education in Nigeria is bedeviled with certain debilitating challenges. This paper examines some of the challenges of teaching and learning English in public secondary schools in Nigeria. It identifies such problems as poor quality of pupils admitted to secondary school, incompetent teachers of English, poor methodology and lack of motivation among others. The paper concludes that effective teaching of English language is a sine qua non for meaningful development in Nigeria and emphasizes the need for collective efforts in this direction. It recommends better training and retraining of teachers through continuing professional development practices and better commitment on the part of the government to the course of English studies in schools in Nigeria.
\end{abstract}

Key words: Challenges, Effective teaching, Learning, English, Secondary schools, Nigeria.

JEL Classification: ZO.

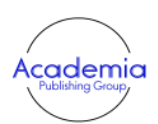

International Journal of Educational Studies

Volume 4, Issue 4, pp. 154-158

2021

DOI: $10.53935 / 2641-533 x . v 4 i 4.167$

Email: murana.muniru@fubk.edu.ng Funding: This study received no specific financial support.

Article History:

Received: 25 October 2021

Revised: 15 November 2021

Accepted: 6 December 202

Published: 21 December 2021

(C) 2021 by the authors; licensee Academic

Publishing Group

\section{Introduction}

English language occupies a pride of place not only in the existence of Nigeria as a nation comprising of varied ethnic and linguistic groups but also in all her developmental efforts. It is the language of her creation, unification and sustenance. By its origin, English is a foreign language and language of imperialism whose introduction was a complement of the selfishness of the colonizers. The reality of the amalgamation and formation of Nigeria as a nation and the centrality of English language in the process, however, remain a paradox. Today, Nigeria is a nation of nations and English a foreign and single most acceptable national language. It is a second language of unique repute.

As Anyanwu (2017) notes, Nigeria is a multilingual nation where English is a second language to many and first language to a few others. This linguistic situation and more so the fissiparous tendency of Nigerians suggests very strongly indeed that English language will continue to enjoy its current no-rival status for quite a long time if not till eternity. The logical corollary expectation, therefore, is that the system of education in Nigeria makes communication in English expressly possible for the citizens so that they can be functional and useful to the society. But the reality is that most secondary school leavers today cannot communicate meaningfully in English, some cannot perform simple operation like withdrawing money from Automated Teller Machine or help illiterate neighbours to fill in national identity card request form. This situation is further compounded by the fact that there are far more illiterate Nigerians than the literate ones. There is the need then to first examine the place of English in secondary education in the country before discussing the challenges facing its teaching-learning. 


\section{English Language and Secondary Education in Nigeria}

Secondary education in Nigeria is offered at the junior and senior secondary school levels. Each level lasts for a period of three years at the end of which an external examination is conducted and a certificate is issued. Thus, a complete secondary education takes a period of six years. The broad goals of secondary education are to prepare the learner for useful leaving in society and to train him or her for higher education (FGN, 2005). Public secondary schools are by the prescription of the education policy tuition free. If these schools are effective, the factor of free tuition fee is potent enough to attract most if not all parents. But only parents who cannot afford the tuition fees charged by private schools enrol their children in public secondary schools in Nigeria today for lack of efficacy of the schools. This is quite frustrating and worrisome.

English language is the language of instruction at both levels of secondary school. Other school subjects besides languages are taught and learned through the medium of English. Besides, English is the first of the core subjects throughout the secondary education curricular and it is required to feature daily on the lesson timetable from junior secondary school through senior secondary school. Tsiga (2001) provides justification for the unique status of English in the secondary school curricular:

Every child must study English in order to be able to follow

the teaching in the classroom, write his examinations

and communicate with his fellow students. He must learn

English well to have a successful job when he leaves school,

holds public office or aspires for any meaningful career.

Tsiga's validation is an interpretation of the broad goal of education in Nigeria and it serves to consolidate the links between English language and education in country. Two basic assumptions have been identified as responsible for the position of FGN (2005) concerning secondary education and the primacy of English. Afolayan (1995) argues that 'the first is that the primary instrument for Nigerian development is English' while the second is 'that education is the agent for enabling the English language to develop Nigeria and Nigerians.' Proficiency in English is a measure of good secondary education. Thus, the syllabus is usually designed to ensure high level of proficiency in the language so as to prepare school leavers for tertiary education or for the world of work. But important documents such as the curriculum and syllabus are not the end in themselves, they are simply requisite preliminaries.

The pedagogical role of English in secondary education requires that the learners are proficient enough to understand the contents of other school subjects taught in English. Accordingly, Banjo (1989) among other scholars has argued that failure in other school subjects are occasioned by failure in the language of instruction, English. This is quite logical since learning takes place through comprehension which in turn is hardly possible when the language of discourse is not understood. Afolayan (1995) argues that the English language education in Nigeria has been characterized by ineffective presentation which has affected the performance of the students. There abound also glaring evidences correlating students' performances in English with their general achievement in education (Murana, 2015). Muhammad (1995) similarly observes that 'students' proficiency in English as measured by WAEC examinations, seems to be declining rapidly particularly since the introduction of SSCE in 1998.' This paper, against the foregoing, examines the enervating challenges facing the teaching and learning of English in secondary schools in Nigeria.

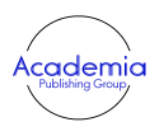

International Journal of Educational Studies

Volume 4, Issue 4, pp. 154-158

2021

DOI: $10.53935 / 2641-533 x . v 4 i 4.167$

Email: murana.muniru@fubk.edu.ng

Funding: This study received no specific

financial support.

Article History:

Received: 25 October 2021

Revised: 15 November 2021

Accepted: 6 December 2021

Published: 21 December 2021

(C) 2021 by the authors; licensee Academic

Publishing Group

$$
\text { | } 155
$$

\section{The Challenges of Effective Teaching and Learning of English in Nigeria}

Effective teaching-leaning of English refers to the enabling processes and activities involved in the English language education leading to desirable students' achievements which correlate with the aims stated in the program curriculum and or syllabus. These in Nigeria include high proficiency in the students' use of English and evident readiness of the students for the next level of education at the point of graduation. There are quite a number of challenges hindering effective teaching and learning of English in Nigeria making the achievement of these aims in most cases a mirage. This is quite unfortunate in a context where English is the national language and the language of peace, unity and above all, development. Some of these debilitating challenges are discussed in this section of the paper.

The major desire of Nigerian pupils leaving primary school which is also the aspiration of their parents is to acquire secondary education. The National Policy on Education of the FGN (2005) anticipates that sixty percent of the pupils would desire secondary education. In some parts of the country, the percentage is far higher. However, majority of these primary school leavers admitted to acquire secondary education are not as 
literate or proficient in English as required. Muhammad (1995) in this connection note that 'many students come to secondary school knowing little or no English thereby necessitating the continued use of mother tongue as a medium for teaching other subjects in some instances.' The task of the English language teacher becomes herculean if not impossible. After all, English language teaching in formal schools is guided by certain curriculum; syllabus and scheme of work designed to suit the purpose of the learner and meant to be used within stated period of time. During the teaching learning process, the misfit is either frustrated or ignorantly complacent while the teacher is equally dissuaded. This is a major cause of the increasing phenomenon of dropout currently evident in most states of the nation. This situation contravenes the major objectives of primary education which according to Olugbodi (2001) are to inculcate permanent literacy and numeracy and ability to communicate effectively.

Fuller (1985) emphasizes the centrality of the language teacher to the success of any language teachinglearning process. Besides the poor products that the teachers of English at the secondary school levels in Nigeria have to grapple with, the teachers in most cases are themselves deficient. Olusoji (2012) provides a clue to this deficiency as he argues that 'majority of the teachers who teach the language are incompetent' because the teachers are equally 'victim of incompetent teaching.' This presupposes that the problem is rather generational and requires drastic measure. Olaofe (2013) argument that 'the evil of poor teaching of English at a particular educational level has a disastrous effect on the other levels' is quite apt in this regards.

Lack of competence makes effective teaching a serious challenge to the teachers. Some are grossly inept in both the knowledge of contents and pedagogy. Others are simply too rigid to be effective. Many practicing teachers are 'glued to the old method of teaching English transmitted across levels' (Olaofe, 2013). A large number of the teachers are slaves to the student's reader or teacher's guide and are bereft of requisite resourcefulness. They lack the required ability to synthesize available materials and provide the students with the needed skills. Teachers of English still compartmentalize language skills in the era of integration and as such find it difficult to help the students achieve the desired communicative competence. The paucity of qualified and experience teachers of English is thus one of the most critical problems facing Nigerian secondary schools today (Muhammad, 1995). The language teacher's quality is naturally a product of the teacher's mastery of the subject-matter, use of appropriate teaching-learning strategy and positive professional attitude (Tatto, Nielsen, \& Cummings, 1991). Thus, a qualitative teacher is an embodiment of many values.

English is taught and learnt in Nigeria as a second language and the environment is not supportive enough. Most learners in the public secondary schools are from parents who do not speak English making interaction with their parents in the language impossible. Some educated immigrants in different parts of Nigeria also believe that their children must speak their mother tongues at home which is the only opportunity such children have to acquire the languages of their parents. Consequently, they do not speak English in their homes. The children from such homes whether in public or private schools have learnt to characterize English as the school language. More encompassing is the negative attitude of parents especially in the Northern part of the country to English language. Adegbite (1994) states succinctly concerning the North that 'in homes, schools, mosques and even in public offices and functions, the English language is often openly resented.' With poor classroom interaction in English emanating from the teachers' limited versatility and stilted pedagogical approach and hostility from outside the classroom, it is perhaps usual for the achievements in English teaching and learning to remain poor. This is supported by the argument of Afolayan (1995) that learners of English as second language just as the native learners require exposure to English in its rich data varieties in both holistic and repetitive manner. Nigerian learners of English in most cases lack opportunity to practice, repeat, access and produce ample texts in the language. The situation in Nigeria is obviously adverse and in such a context as Olaofe (2013) notes:

Learners of English are exposed to limited comprehensible

language input thus leading to gross inadequate output.

The kind of English learners hear, imitate, repeat and

ultimately produce is largely faulty, erroneous and

substandard, especially when the quality of English

coming from teachers, newspapers, radio and

television broadcast are full of substandard patterns.

In these kinds of infelicitous immediate and wider teaching-learning situations, the production of quality and proficient learners is a hardly realistic. 


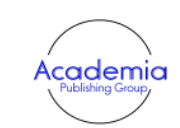

International Journal of Educational Studies

Volume 4, Issue 4, pp. 154-158

2021

DOI: $10.53935 / 2641-533 x . v 4 i 4.167$

Email: murana.muniru@fubk.edu.ng

Funding: This study received no specific

financial support.

Article History:

Received: 25 October 2021

Revised: 15 November 2021

Accepted: 6 December 2021

Published: 21 December 2021

(C) 2021 by the authors; licensee Academic

Publishing Group
In most of the public secondary schools in Nigeria, teachers of English do not have a department of their own. Thus, there is no such position as Head of Department of English. This perhaps points to the fact that often the teachers of English are few in number even in schools with very large population of students. This practice underrates the enormity of the task of effective English language teaching. The teachers work individually hoping to achieve a collective goal. The practice does not stress the place of experience, the need for mentorship and the primacy of collectivism in modern endeavours. The teachers also hardly engage in continuing professional development and majority are technophobic in the era of speedy evolution of information and communication technology. There is hardly any functional professional association for the teachers of English in secondary schools in Nigeria and as such teachers at this level miss a range of activities for their professional development and this greatly affects their performance. The effective teacher after all is the developing teacher and it is never possibly for the teacher of English to effectively stand still (M. O Murana, 2004)

Perhaps another major challenge to the teaching-learning of English in Nigeria is lack of motivation. Most of the teachers nowadays lack the enabling passion and interest in language teaching and English language teaching is hardly seen as a calling. The teachers' salary in most cases is dissuading and more so in the contest of the demands of modern life and the poor value of Naira. Consequently, the teachers of English are neither intrinsically nor extrinsically motivated. Besides, the learners' attitude to learning does not motivate the willing teachers. They are hardly cooperative or willing to spend extra time on learning. They prefer spending their time on social network uploading their pictures and downloading music and films. 'Their interest or pleasure in English language activities is generally not existent' (Olaofe, 2013).

The availability of miracle centres where students are illegally assisted to write and pass their terminal external examination conducted by the West African Examination Council (WAEC) and National Examination Council (NECO) nationwide is a major threat to students' commitment to academic generally and English language learning specifically. Desperate parents including highly educated ones register their children in such centres to ensure undeserved success. This practice drains the respect and authority of the English language teachers; dampens the morale of the few conscientious ones; and discourages industry among students.

\section{Conclusion}

English language is a second language that needs to be effectively taught and leant in secondary schools in Nigeria for its unique role in national unity and both personal and national development. The current challenges to the teaching-learning of English and the consequent poor level of proficiency of most secondary school leavers who are admitted to read varied courses in the universities is grossly affecting the success of university education in Nigeria. This is especially so as failure or poor level of communicative performance in English is a measure of failure of education and consequently national development. Thus, this trend must be reversed in order to achieve not only the broad goals of secondary education in Nigeria but also to pave way for qualitative university education and national growth.

\section{Recommendations}

In view of the various challenges discussed in this paper, it is recommended that:

a. The primary school education generally and English language teaching and learning be revitalized by the government of Nigeria;

b. The departments of English in colleges of education and faculties of education in the universities ensure production of competent teachers through dynamic and good quality teaching in both aspects of contents and pedagogy as well demonstrated emphasis on resourcefulness;

c. Teaching of English should not be left for the teachers of English alone, both educated parents and teachers of other subjects should be concerned;

d. The practicing teacher should be motivated through better salary and good conditions of service;

e. Activities of miracle centers should be checked and people behind them punished; and

f. Teachers of English should be exposed to varied forms of continuing development activities such as workshop, mentoring, peer observation, self observation, etc. 


\section{References}

Adegbite, E. (1994). The context of language planning in Africa: An illustration with Nigeria. In P. Martins (Ed.), Language Context and Language Conflict (pp. 145-153). Amsterdam: Philadelphia Company.

Afolayan, A. (1995). 'Ineffectiveness in the presentation of English in Nigeria: Sources and remedy. In A. Bangbose and A. Banjo (Eds.), New Englishes (pp. 113-129). Ibadan: Mosuro Publishers.

Anyanwu, E. C. (2017). The indispensable role of the English language in sustainable development: The Nigerian case. AFRREV LALIGENS: An International Journal of Language, Literature and Gender Studies, 6(2), 79-85. Available at: https://doi.org/10.4314/laligens.v6i2.7.

Banjo, A. (1989). The status and roles of English as a second language in Nigeria. Educational Forum, 12(1), 1-4

FGN. (2005). National policy on education. Lagos: NERDC.

Fuller, S. B. (1985). Raising school quality in developing countries: What investiment boost learning? Washington DC: The World Bank Education and Training Department Report ED 17.

Muhammad, A. (1995). Communicative competence acquisition in infelicitous learning environment: The problem with SSS English in Nigeria. In A. Bangbose and A. Banjo (Eds.), New Englishes (pp. 130-177). Ibadan: Mosuro Publishers.

Murana, M. O. (2004). Challenges of effective teaching and learning of English in colleges of education, in Nigeria. Paper presented at the National Conference School of Languages, Federal College of Education, Katsina, Katsina State, Nigeria.

Murana, M. O. (2015). Effective English language education for national development. Paper presented at the Faculty of Arts Conference, Obafemi Awolowo University, Ile-Ife, Osun State, Nigeria (2015).

Olaofe, I. (2013). Teaching English in second language adverse situation. Zaria: Yahaya Ventures.

Olugbodi, S. A. (2001). Problems of language teaching in public vis-à-vis private schools. In M. B. Umar (Ed.), Effective Language Teaching (pp. 145-153). Zaria: FCE, Zaria.

Olusoji, O. A. (2012). Effects of English language on national development. Greener Journal of Social Sciences, 2(4), 134-139.

Tatto, M. T., Nielsen, D., \& Cummings, W. (1991). Comparing the effects of cost of different approaches for educating primary school teachers: The case of Srilanka. Srilanka: BRI

Tsiga, I. A. (2001). The place of language in secondary school curriculum. In M. B. Umar (Ed.), Effective Language Teaching (pp. 145-153). Zaria: FCE Zaria.

\author{
International Journal of Educational \\ Studies \\ Volume 4, Issue 4, pp. 154-158 \\ 2021 \\ DOI: 10.53935/2641-533x.v4i4.167 \\ Email: murana.muniru@fubk.edu.ng \\ Funding: This study received no specific \\ financial support. \\ Article History: \\ Received: 25 October 2021 \\ Revised: 15 November 2021 \\ Accepted: 6 December 2021 \\ Published: 21 December 2021 \\ (C) 2021 by the authors; licensee Academic \\ Publishing Group
}

